\title{
Alternation between dietary protein depletion and normal feeding cause liver damage in mouse
}

\author{
Veronica J. Caballero • Julieta R. Mendieta • Ana M. Giudici • \\ Andrea C. Crupkin • Claudio G. Barbeito • Virginia P. Ronchi • \\ Andrea N. Chisari • Ruben D. Conde
}

Received: 9 June 2010 / Accepted: 15 September 2010 /Published online: 29 September 2010

(C) University of Navarra 2010

\begin{abstract}
The effect of frequent protein malnutrition on liver function has not been intensively examined. Thus, the effects of alternating 5 days of a protein and amino acid-free diet followed by 5 days of a complete
\end{abstract}

V. J. Caballero · J. R. Mendieta $\cdot$ A. M. Giudici

V. P. Ronchi - A. N. Chisari - R. D. Conde Instituto de Investigaciones Biológicas,

Facultad de Ciencias Exactas y Naturales,

Universidad Nacional de Mar del Plata-CONICET,

Funes $32504^{\circ}$ nivel,

CP 7600 Mar del Plata, Argentina

\section{A. C. Crupkin}

Laboratorio de Ecotoxicología, Departamento de Ciencias

Marinas,

Facultad de Ciencias Exactas y Naturales,

Universidad Nacional de Mar del Plata,

Funes 3350,

CP 7600 Mar del Plata, Argentina

C. G. Barbeito

Laboratorio de Histología y Embriología,

Escuela de Ciencias Veterinarias,

Universidad Nacional de La Plata,

Calle 60 y 118 ,

CP 1900 La Plata, Argentina

\section{R. D. Conde $(\bowtie)$}

Instituto de Investigaciones Biológicas,

Universidad Nacional de Mar del Plata-CONICET,

CC 1245,

Mar del Plata CP 7600 Buenos Aires, Argentina

e-mail: rdconde@mdp.edu.ar diet repeated three times (3 PFD-CD) on female mouse liver were examined. The expression of carbonic anhydrase III (CAIII), fatty acid synthase (FAS), glyceraldehyde 3-phosphate dehydrogenase (GAPDH) and glutathione $S$-transferase P1 (GSTP1) in liver were assessed by proteomics, reverse transcriptase-polymerase chain reaction and Northern blotting. The activities of liver GSTs, glutathione reductase (GR) and catalase (CAT), as well as serum glutamic-oxaloacetic transaminase (SGOT) and glutamic-pyruvic transaminase (SGPT) were also tested. Additionally, oxidative damage was examined by measuring of protein carbonylation and lipid peroxidation. Liver histology was examined by light and electron microscopy. Compared with control mice, 3 PFD-CD increased the content of FAS protein $(+90 \%)$ and FAS mRNA $(+30 \%)$, while the levels of CAIII and CAIII mRNAs were decreased $(-48 \%$ and $-64 \%$, respectively). In addition, 3 PFD-CD did not significantly change the content of GSTP1 but produced an increase in its mRNA level $(+20 \%)$, while it decreased the activities of both CAT $(-66 \%)$ and GSTs (-26\%). After 3 PFD-CD, liver protein carbonylation and lipid peroxidation were increased by $+55 \%$ and $+95 \%$, respectively. In serum, 3 PFDCD increased the activities of both SGOT $(+30 \%)$ and SGPT (+61\%). In addition, 3 PFD-CD showed a histological pattern characteristic of hepatic damage. All together, these data suggest that frequent dietary 
amino acid deprivation causes hepatic metabolic and ultrastructural changes in a fashion similar to precancerous or cancerous conditions.

Keywords Mouse liver. Cycles of protein depletion . Liver damage $\cdot$ Oxidative stress

\section{Introduction}

Protein malnutrition causes severe metabolic changes in mammalian liver $[1,2,7,8,16,21,24,41]$. However, the extent to which periodic dietary protein deprivation affects liver function has not been intensively examined.

Previously, we have found that mouse liver protein content decreases by $50 \%$ after 5 days of subjecting mice to a diet that lacks amino acids and protein (protein free diet (PFD)), while it is rapidly restored by administration of a complete diet (CD) [10]. In addition, the content of several cytosolic proteins depends on the amino acid intake [31, 33, 36, 37]. It also has been reported that subjecting mice to a 5-day PFD diet produces changes in the liver content of glyceraldehyde-3-phosphate dehydrogenase (GAPDH), glutathione $S$-transferase subunits (GSTs), carbonic anhydrase III (CAIII), fatty acid synthase (FAS) and $\mathrm{Cu} / \mathrm{Zn}$ superoxide dismutase (SOD) [15, $33,36,37]$. Conversely, these changes are reverted by feeding a $\mathrm{CD}$ for 2 days $[15,36]$. Additionally, we have recently shown that feeding mice a PFD for 5 days causes hepatic oxidative stress [34]. Interestingly, it has been reported that changes in GSTP1 subunit, GAPDH, FAS and CAIII can be used as markers for precancerous, cancerous or senescent conditions in the liver tissue [4, 6, 23].

Based on our previous observations on the effects of a 5-day PFD on mouse liver, we examined how three successive cycles of 5-day PFD followed by 5 days of $\mathrm{CD}$ (3 PFD-CD) affect mouse liver function. For this purpose, we measured protein and mRNA content of CAIII, FAS, GSTP1 and GAPDH, as well as the activities of catalase (CAT), GSTs and glutathione reductase (GR), total content of carbonyl groups and lipid peroxidation in liver. In addition, serum markers for liver damage and hepatic ultrastucture were determined. Taken together, our results show that periodic protein malnutrition affects liver function in a harmful manner.

\section{Materials and methods}

Animals

Two-month-old female Balb/c mice (body weight, 20-25 g) from IIB, UNMdP-CONICET, Mar del Plata, Argentina were kept in a room at $22^{\circ} \mathrm{C}$ illuminated from 7:00 to 19:00 hours. They had ad libitum access to complete diet and water and kept in accordance with the National Institutes of Health Guide for the Care and Use of Laboratory Animals. The local ethical committee for animal research approved the protocols used in this study.

Diets

All diets used were based on the PFD outlined by the USP XV Pharmacopoeia and the amino acid composition of bovine $\beta$-casein $[12,42]$. Normal or complete diet $(\mathrm{CD})$ containing $23 \%(w / w) \beta$-casein was prepared as described by Ronchi et al. [33]. Because carbohydrates replace protein and amino acids, all diets are isocaloric. Mice consumed 2.53 \pm 0.29 and $3.38 \pm 0.14 \mathrm{~g}$ a day of $\mathrm{CD}$ and PFD, respectively.

The test mouse group was subjected to three cycles of 5 days of PFD followed by 5 days of CD. The control group was fed a $\mathrm{CD}$ throughout the entire experiment. After the treatment, animals were killed by cervical dislocation, and livers were rapidly removed, weighed and placed in buffer A $(0.15 \mathrm{M}$ $\mathrm{NaCl}, 1 \mathrm{mM}$ EDTA, $5 \mathrm{mM} \beta$-mercaptoethanol and 20 mM Tris- $\mathrm{HCl}$ buffer; $\mathrm{pH}$ 7.4).

Cytosol preparation

Livers were homogenized in $5 \mathrm{ml} / \mathrm{g}$ fresh weight of cold buffer A. The supernatant obtained by centrifugation at $100,000 \times \mathrm{g}$ for $10 \mathrm{~min}$ represents the cytosol [37].

Cytosolic enzymes were extracted according to Wiegand et al. [47], with some adjustments. Briefly, each liver was homogenized in $0.1 \mathrm{M}$ potassium phosphate buffer $\mathrm{pH} 6.5$ containing $20 \%(v / v)$ glycerol, $1 \mathrm{mM}$ EDTA and $14 \mathrm{mM}$ 1,4-dithioerythritol (DTE). Cell debris was removed by centrifugation at $10,000 \times g$ for $10 \mathrm{~min}$. The supernatant was centrifuged at $100,000 \times g$ for $60 \mathrm{~min}$, and the soluble cytosolic fraction was immediately frozen with liquid nitrogen 
and stored at $-80^{\circ} \mathrm{C}$ until use. Activity of total glutathione $S$-transferases (GSTs) was determined according to Habig et al. [17]. Glutathione reductase (GR) was tested according to Tanaka et al. [40]. Catalase (CAT) was determined according to Claiborne [9]. Results were expressed in nanokatals per milligram of protein (nkat/mg prot), where 1 kat represents the conversion of $1 \mathrm{~mol}$ of substrate per second. Each test was carried out in triplicate.

Protein and nucleic acid determination

Protein concentration was determined according to Bradford [5] using bovine serum albumin as a standard. Nucleic acid concentrations were determined by the method described by Fleck and Munro [14].

Polyacrylamide gel electrophoresis

Cytosol samples were subjected to sodium dodecyl sulphate-polyacrylamide gel electrophoresis (SDSPAGE) in $12 \%$ acrylamide under reducing conditions [25] followed by staining with Coomassie blue [28]. Resulting protein patterns were photographed and analyzed with the computer image analyzer system ImageQuant TL v2005. It may be noted that CAIII, FAS and GSTP1 bands were previously identified and quantified using mass spectroscopy combined with sequence analysis of peptide produced by in-gel trypsin digestion $[15,33]$. In addition, GAPDH band was identified and quantified by both Western blot test and N-term amino acid sequence [36].

Reverse transcriptase-polymerase chain reaction

Total liver RNA was extracted with Trizol (Invitrogen, Gaitherburg, MD, USA). Extracts were treated with RQ1 RNase-Free DNase (Promega), quantified by measuring the absorbance at 260/280 nm and tested for quality by agarose $1 \%$ native gel electrophoresis. First-Strand cDNA synthesis was generated with MMLV reverse transcriptase (Invitrogen) and oligo dT primers and used for reverse transcriptase-polymerase chain reaction (RT-PCR). Products were obtained after 30-35 cycles of amplification considering the exponential phase for each probe and $55-65^{\circ} \mathrm{C}$ annealing temperatures. RT-PCR products were separated on $2 \%$ agarose gels. Electrophoresis was carried out at $100 \mathrm{~V}$ for $60 \mathrm{~min}$ in TBE $1 \mathrm{X}$ buffer (0.89 M Tris, $0.89 \mathrm{M}$ borate, $2 \mathrm{mM}$ EDTA). The gels were stained with SYBR $^{\circledR}$ Gold nucleic acid stain (Molecular Probes, Eugene, OR, USA). Bands were detected with a Scanner Storm Amersham Biosciences and quantified by ImageQ TL v2005. All the band intensities were related to actin.

Mouse specific primer sequences for PCR reaction

FAS: FW, 5'-TGC GCC CAG CCT CCT AAG GC3'; RV, 5'-ATC ACA CGC CGG CAA CAC CTA TCC-3'

CAIII: FW, 5'-TGC CAA AGG GGACAA CCA GT-3'; RV, 5'-GCA CCG GGG GCTCAT TCT C-3'

GAPDH: FW, 5'-ACG GCA AAT TCA ACG GCA CAG TCA-3'; RV, 5'-CAT TGG GGG TAG GAA CAC GGA AGG-3'

GSTP1: FW, 5'-ATG CCA CCA TAC ACC ATT GT-3'; RV, 5'-GTC CAG CAA GTT GTA ATC GG-3'

Actin: FW, 5'-AGT ACT TGC GCT CAG GAG GA-3'; RV: 5'-TCC TCC CTG GAG AAG AGC TA-3'.

Northern blotting

Total RNA was extracted from livers using $4 \mathrm{M}$ guanidinium thiocyanate followed by extraction with phenol [35]. The extract was dissolved in water $\mathrm{DEPC}$, quantified and stored at $-80^{\circ} \mathrm{C}$ for further tests. Thirty microgrammes of RNA per condition were denatured for $1 \mathrm{~h}$ in GLYOXAL at $55^{\circ} \mathrm{C}$ [43], separated by electrophoresis on agarose gels $1.5 \%$ $(w / v)$ and transferred onto a nylon membrane (Amersham, UK).

DNA probes were obtained by PCR amplification with specific primers (see above) using DNA as template. Then, the probes were labelled by random priming (Invitrogen, Life Technologies, DNA labelling System) using [32P] dCTP. Probes were purified by chromatography in G-50 Sephadex columns. Sequential hybridization with the different probes was performed using standard methods. The intensity of the bands was detected by Scanner Storm (Amersham Biosciences) and quantified by ImageQuant TL v2005. All the band intensities were related to actin. 
Serum analyses

Blood was collected in $1.5 \mathrm{ml}$ tubes after beheading the animals by guillotine. Blood collection was performed between 8:00 and 10:00 am and kept in $37^{\circ} \mathrm{C}$. Within $15 \mathrm{~min}$, the samples were centrifuged for $10 \mathrm{~min}$ at $1,000 \times \mathrm{g}\left(4^{\circ} \mathrm{C}\right)$ to separate the serum. Samples were kept at $-80^{\circ} \mathrm{C}$ until determination of serum components.

Serum glutamic-oxaloacetic transaminase (SGOT) and serum glutamic-pyruvic transaminase (SGPT) were measured by using a commercial kit (Wiener Lab, Rosario, Argentina) and performed according to the appended protocol.

Measurement of protein carbonyl content

The reactive carbonyl content of liver proteins was measured according to Ronchi et al. [34]. Briefly, livers were homogenized at $4^{\circ} \mathrm{C}$ in $10 \mathrm{ml} / \mathrm{g}$ fresh weight of cold $0.15 \mathrm{M} \mathrm{NaCl}, 1 \mathrm{mM}$ EDTA and $20 \mathrm{mM}$ Tris- $\mathrm{HCl}, \mathrm{pH}$ 7.4. Two $0.75-\mathrm{ml}$ aliquots per sample containing nearly $1 \mathrm{mg}$ protein were mixed with $0.75 \mathrm{ml}$ of $20 \%(w / v)$ trichloroacetic acid (TCA). The pellets were separated by centrifugation at $6,000 \times g$ for $5 \mathrm{~min}$, mixed with either $0.75 \mathrm{ml}$ of $2 \mathrm{~N} \mathrm{HCl}$ (blank) or $0.75 \mathrm{ml}$ of $2 \mathrm{~N} \mathrm{HCI}$ containing $0.2 \%(w / v)$ dinitrophenylhydrazine (DNPH) and agitated for $1 \mathrm{~h}$ at $25^{\circ} \mathrm{C}$ in the dark. Then, they were re-precipitated with $0.75 \mathrm{ml}$ of $20 \%(w / v)$ TCA, washed three times with ethanol:ethyl acetate $(1: 1, v / v)$, dried and mixed with $0.75 \mathrm{ml}$ of $6 \mathrm{M}$ guanidine $\mathrm{HCl}$ at $25^{\circ} \mathrm{C}$. After removing the debris by centrifugation, absorbance at $370 \mathrm{~nm}$ of DNPH-treated samples after subtraction of blanks was assessed. This value was used to calculate the nanomoles of DNPH incorporated per milligramme of protein based on an average absorption of $21 \mathrm{mM}^{-1} \mathrm{~cm}^{-1}$ for aliphatic hydrazones [22].

Lipid peroxidation test

Thiobarbituric acid reactive substances (TBARS), indicative of lipid peroxidation level, were evaluated as showed by Oakes and Van Der Kraak [30] with adjustments. Briefly, $50 \mathrm{mg}$ of fresh liver were homogenized in $450 \mu \mathrm{l}$ of a solution containing $0.15 \mathrm{M} \mathrm{KCl}$ and $35 \mu \mathrm{M}$ butylated hydroxytoluene (BHT). Homogenate aliquots of $100 \mu \mathrm{l}$ were added to
$3.9 \mathrm{ml}$ of a reaction mixture containing $37.5 \mathrm{mM}$ TBA, $67 \mu \mathrm{M}$ BHT, 7.5\% (w/v) TCA and $0.4 \%(w / v)$ SDS. Then, samples were heated at $95^{\circ} \mathrm{C}$ for $30 \mathrm{~min}$, cooled to $15^{\circ} \mathrm{C}$, and centrifuged at $3,000 \times g$ for $10 \mathrm{~min}$. Optical density at $532 \mathrm{~nm}$ of supernatants, through a molar extinction coefficient of $1.56 \times$ $105 \mathrm{M}^{-1} \mathrm{~cm}^{-1}$, allowed assessing the TBARS content in nanomoles by milligramme of tissue [30].

Histological studies

For morphological observation by light microscopy, liver tissues were fixed in 10\% neutral formaldehyde solution, dehydrated in an ascending ethanol series and embedded in paraffin. Sections were stained with haematoxylin and eosin (H\&E) and periodic acidSchiff (PAS). The structures of liver lobules, hepatocytes, portal tracts and sinusoidal and perisinusoidal acini were analyzed.

For electron microscopy analysis, the samples were fixed in glutaraldehyde $2 \%$ in buffer phosphate (pH 7.4) for $2 \mathrm{~h}$ and washed twice with buffer solution for $30 \mathrm{~min}$. Then, they were post-fixed in $1 \%$ osmium tetroxide, dehydrated in a series of alcohol and embedded in Epon 812 for ultra-thin sectioning. Ultrathin sections, 60-80-nm thick, were cut with a diamond knife on an ultramicrotome (ultramicrotome supernova, Reichert-Jung) and then viewed under a transmission electron microscope (JEM 1200EX II, Jeol).

Statistical analysis

All data are presented as means \pm SEM. Data comparison was performed using unpaired twotailed Student's $t$ test (InStat, Graph Pad software). $P$ values lower than 0.05 were considered significant. Data analysed include at least three separate experiments.

\section{Results}

General properties

After 3 PFD-CD, body weight of treated mice declined to a value near $20 \%$ lower than the control (Fig. 1). Figure 1 also shows that major body weight loss happened during the PFD periods. The treatment 


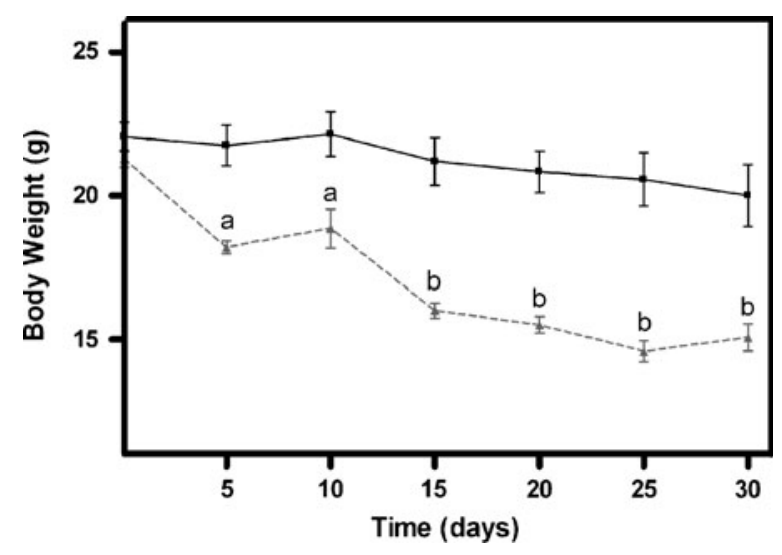

Fig. 1 Changes in body weight. Treatment groups were (gray triangle) PFD-CD and (black square) CD. Weights are the means \pm SEM of three independent experiments $(n=6$ for each experiment). Values significantly different from the $\mathrm{CD}$ group: ${ }^{\mathrm{a}} P<0.001,{ }^{\mathrm{b}} P<0.0001$

did not change either the weight or DNA content of the liver but showed a tendency to increase RNA $(+19 \%)$ and protein $(+23 \%)$ content. Control mice (CD diet) displayed the following properties: liver weight, $1.03 \pm 0.03 \mathrm{~g}$; DNA, $1.47 \pm 0.26 \mathrm{mg} / \mathrm{liver}$; RNA, $4.47 \pm 0.43 \mathrm{mg} /$ liver; total protein, $144.12 \pm$ $9.30 \mathrm{mg}$.

\section{Liver content of CAIII, FAS, GAPDH and GSTP1}

The effect of 3 PFD-CD on CAIII, FAS, GAPDH and GSTP1 content was assessed by densitometry of SDS-PAGE bands (Fig. 2). FAS increased $90 \%$ and CAIII decreased $48 \%$, while both GAPDH and GSTP1 did not show a significant change. Western blotting confirmed the results obtained by SDS-PAGE for both FAS and GSTP1 (not shown).

\section{Liver content of CAIII, FAS, GAPDH and GSTP1} mRNAs

To find out whether the effects of 3 PFD-CD observed on CAIII, FAS, GAPDH and GSTP1 content depend on changes in mRNA content, Northern blot and RT-PCR experiments were carried out. In agreement with protein content, FAS mRNA increased $30 \%$ and CAIII mRNA decreased by $64 \%$. On the other hand, GSTP1 mRNA increased $20 \%$, while GAPDH mRNA did not change significantly,
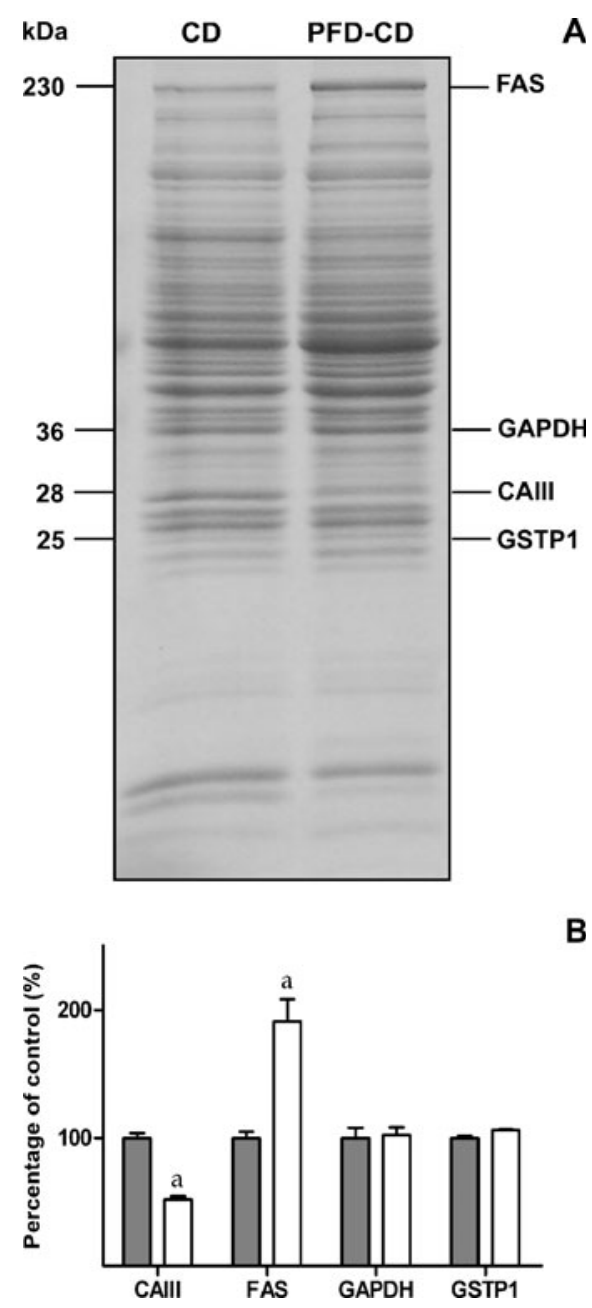

Fig. 2 Effect of 3 PFD-CD on cytosolic protein composition. a SDS-PAGE representative analysis of protein samples $(25 \mu \mathrm{g})$ from $\mathrm{CD}$ and 3 PFD-CD. Positions of size markers are signalled on the left. Bands of FAS, GAPDH, CAIII and mGSTP1 are signalled on the right. b Average percentages of FAS, GAPDH, CAIII and mGSTP1 band densities in 3 PFD$\mathrm{CD}$ (white bars) with respect to $\mathrm{CD}$ (grey bars). Values represent the means \pm SEM of three independent experiments (CD and 3 PFD-CD with $n=6$ each experiments). Values significantly different from the $\mathrm{CD}$ condition: ${ }^{\mathrm{a}} P<0.001$

though individual data displayed high variability (Figs. 3 and 4).

\section{Liver activities of CAT, GSTs and GR}

We also examined whether 3 PFD-CD affect the enzymatic activities of CAT, GSTs and GR in liver. Both CAT and GSTs decreased $66 \%$ and 26\%, respectively, while GR did not change (Table 1). 

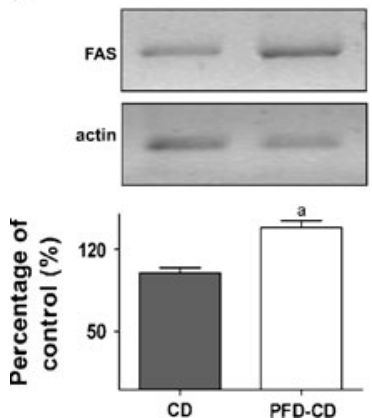

b
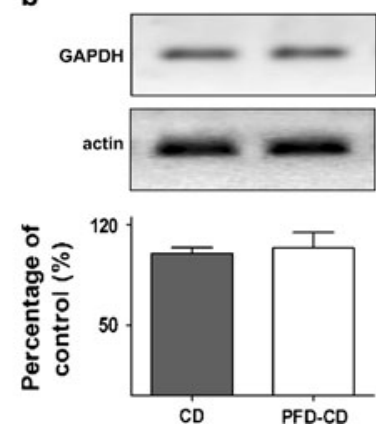

Fig. 3 Effect of 3 PFD-CD on FAS and GAPDH mRNA content. a RT-PCR analysis of FAS mRNA. b RT-PCR analysis of GAPDH mRNA. After dietary treatments, total liver mRNA was isolated, and the levels of FAS and GAPDH mRNAs were assessed by RT-PCR analysis. Actin content was used for RNA normalization. Relative changes in FAS and GAPDH mRNA content were assessed by scanning densitometry of RT-PCR bands. Data are expressed as the intensity of bands determined by densitometry and related to the $\mathrm{CD}$ group. Values represent the means \pm SEM of three independent experiments (CD and 3 PFD-CD with $n=6$ each experiments). Values significantly different from $\mathrm{CD}$ condition: ${ }^{\mathrm{a}} P<0.05$

Carbonyl-group content of protein

We examined the extent of liver oxidative stress by measuring the total protein carbonyl content. This was evaluated by the reaction with DNPH. Carbonyl

a

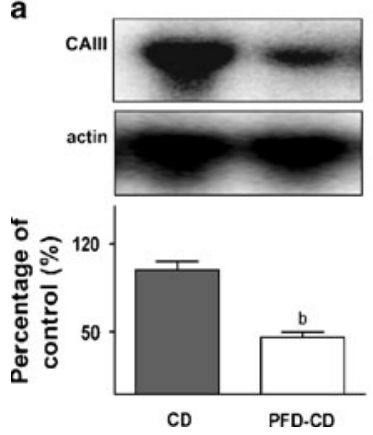

b

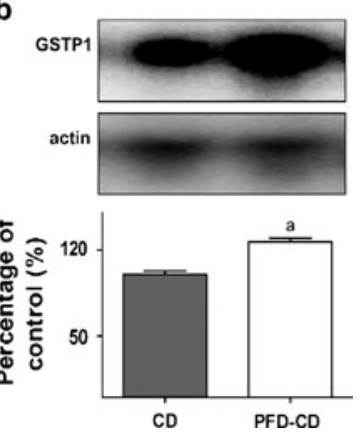

Fig. 4 Effect of 3 PFD-CD on CAIII and mGSTP1 mRNA content. a Northern blot analysis of GSTP1 mRNA. b Northern blot analysis of CAIII mRNA. After dietary treatments, total liver RNA was isolated. Thirty micrograms were subjected to Northern blot analysis using specific cDNA probes for CAIII and GSTP1 mRNAs. Actin cDNA probe was used for RNA normalization. The radioactivity in the Northern blots with different probes was measured by scanning densitometry. Data are expressed as intensity of bands determined by densitometry and related to the $C D$ group. Values represent the means \pm SEM of three independent experiments (CD and 3 PFD-CD with $n=6$ each experiments). Values significantly different from $C D$ condition: ${ }^{\mathrm{a}} P<0.05,{ }^{\mathrm{b}} P<0.001$

Table 1 Activities of liver cytosolic enzymes after dietary treatments

\begin{tabular}{llll}
\hline \multicolumn{4}{c}{ Enzymes activity $($ nkat $/ \mathrm{mg})$} \\
\cline { 2 - 4 } & CAT & GSTs & GR \\
\hline CD & $341.29 \pm 70.69$ & $17.81 \pm 1.18$ & $0.63 \pm 0.06$ \\
3 PFD-CD & $117.04 \pm 67.65^{*}$ & $13.23 \pm 0.79 * *$ & $0.56 \pm 0.03$ \\
\hline
\end{tabular}

Values are means \pm SEM of two independent experiment $(n=4$ each experiments). Values significantly different from $C D$ group

$* P<0.05 ; * * P<0.005$

content significantly increased with 3 PFD-CD when compared with $\mathrm{CD}$, as evidenced by their values $(17 \pm$ 1.5 and $11.2 \pm 0.9$, respectively, $P<0.0001$ ).

Lipid peroxidation

The effect of 3 PFD-CD on liver lipid peroxidation was investigated. The 3 PFD-CD increased $95 \%$ the TBARS levels of liver compared with CD $(0.232 \pm$ 0.02 and $0.119 \pm 0.01$, respectively, $P<0.002$ ).

Serum markers of liver damage

We also examined whether 3 PFD-CD changes the serum content of molecular markers for liver damage. Activities in $\mathrm{U} / \mathrm{L} \pm$ SEM of serum glutamicoxaloacetic (SGOT) and serum glutamic-pyruvic (SGPT) transaminases were SGOT, $472.83 \pm 25.87$ and $611.20 \pm 10.64^{\mathrm{b}}$ for $\mathrm{CD}$ and 3 PFD-CD, respectively; SGPT, $182.25 \pm 13.99$ and $293.50 \pm 45.09^{\mathrm{a}}$, respectively. Values correspond to means \pm SEM of two independent experiments $(n=4)$; values were considered significantly different from the $\mathrm{CD}$ group at ${ }^{\mathrm{a}} P<0.05$ and ${ }^{\mathrm{b}} P<0.001$.

\section{Liver histology}

The liver of CD mice showed the typical lobular structure with normal central veins and portal tract (Fig. 5a). The hepatocytes showed normal cytological structures with well-preserved staining and morphological characteristics of cytoplasm, nucleus and nucleolus (Fig. 5b). Some PAS positive inclusions were found in the cytoplasm of hepatocytes. After 3 PFD-CD, liver sections showed that although the 
Fig. 5 Histology of the liver after 3 PFD-CD treatment. a CD mouse liver shows typical lobular structure with normal central vein and portal tract; $\mathrm{H} \& \mathrm{E}, \times 100$. b CD mouse liver; H\&E, $\times 400$. c The hepatocytes show a vacuolated cytoplasm (v). In some areas, nuclei are absent (arrow); H\&E, $\times 400$. d The cytoplasmic vacuoles are negative to PAS reaction $(\mathrm{v})$. PAShaematoxylin; $\times 400$. e Cytoplasmic vacuolization and lack of normal organelle organization ( $n$, nucleus); TEM, $\times 5,000$
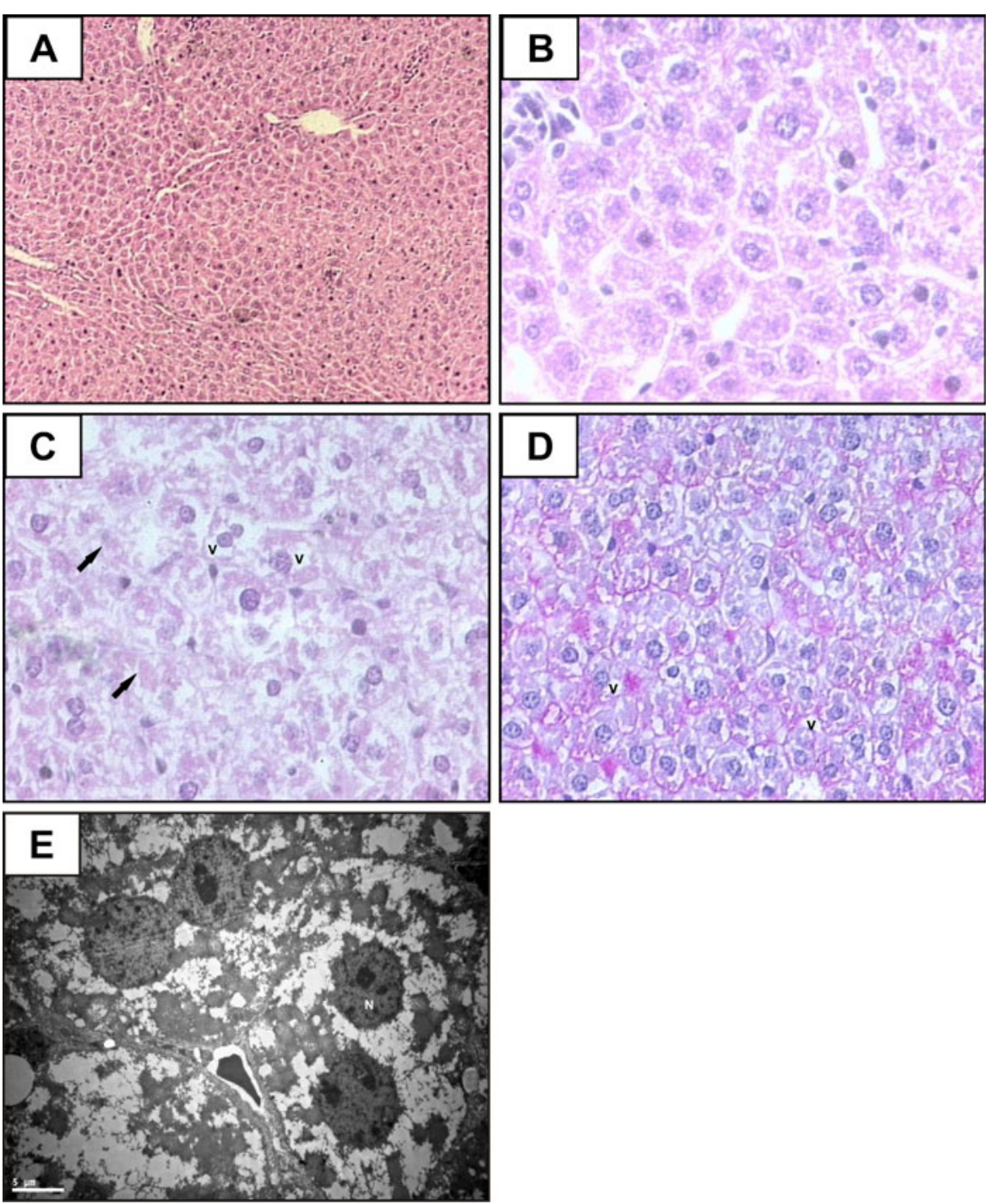

lobular organization was preserved, the hepatocytes displayed a vacuolated cytoplasm. Also, nuclei were absent in some areas (Fig. 5c). In addition, the cytoplasmic vacuoles were negative to PAS and H\&E stain (Fig. 5d). Presence of hepatic damage after 3 PFD-CD was confirmed by electronic microscopy. Hepatocytes from these mice showed a decreased nuclear size with indented nuclear membrane and an increase of the perinuclear aggregation of heterochromatin. Mitochondria organization was abnormal and showed swelling and cristolisis. Vast accumulation of vacuoles representing lipid droplets were also observed in the liver of mice exposed to 3 PFD-CD (Fig. 5e).

\section{Discussion}

This work was aimed to address whether three cycles of feeding a diet lacking amino acids for 5 days followed by a complete diet for 5 days (3 PFD-CD) produce irreversible changes in the protein composition and function of mouse liver.

Similar to rats exposed to three cycles of fastingre-feeding [24], 3 PFD-CD decrease the total body weight while preserving liver weight. This result is consistent with the fast recovery of liver weight in mice fed with a normal diet after 5 days under PFD [10]. Similarly, despite body weight loss, liver weight of fasted rat nearly reaches that of control within few 
days of re-feeding with normal diet [18]. Liver growth during $C D$ feeding is favoured because PFD is isocaloric and taken in rather high amount than $C D$ [26]. Therefore, liver may regained its normal weight during each period of PFD. In addition, 3 PFD-CD does not change liver DNA content but increases slightly RNA and protein levels. These results agreed with those displayed by mice that were fed a CD after the intake of a PFD during 6 days [10].

Because FAS is regulated at the transcriptional level, 3 PFD-CD produces an increase in FAS content caused by an increase in its mRNA. Besides its control by hormonal and nutritional factors [19], it has been recently published that signalling pathways such as AMPK-S6K1 might be involved in FAS induction. Furthermore, is also known that lipogenic enzymes are markedly induced in hepatocellular carcinomas [13, 45, 48]. Thus, the increase in FAS caused by 3 PFD-CD could be associated with the development of hepatocellular carcinoma. In contrast, although GAPDH content increases in hepatic carcinogenesis [3], it remains unmodified after 3 PFD-CD. Based on our previous studies [36], the last 5 days under normal diet in the present experimental model would be enough to restore the content and the mRNA levels of GAPDH.

We had previously noticed that liver content of CAIII decreases after feeding a PFD for 5 days [37]. In this study, although the last feeding period of 3 PFD-CD is CD, both CAIII content and CAIII mRNA decrease with 3 PFD-CD. Besides preserving the acid-base balance, CAIII acts as an oxygen radical scavenger, protecting cells from oxidative damage $[27,32]$. Thus, the down-regulation of this enzyme might promote liver damage and, possibly, lead to hepatocellular carcinoma [23].

GSTs have a prominent role in protecting cells against oxidative stress. Among them, GSTP1 has been proven to increase during detoxification of electrophilic drugs and carcinogens [44]. The content of GSTP1 does not change after 3 PFD-CD, but its mRNA does. Transcription of the GSTP1 gene is activated in both chemically induced and spontaneous precancerous lesions [20, 38]. Thus, the observed GSTP1 mRNA increase could be a marker for an early stage of hepatocarcinogenesis.

In this study, we have also shown that 3 PFD-CD markedly decreases GSTs and CAT activities in liver, therefore increasing oxidative stress, which is revealed by an increment in protein carbonylation and lipid peroxidation. In addition, 3 PFD-CD increases the activities of SGPT $(+61 \%)$ and SGOT $(+30 \%)$, which have been reported as markers for liver damage [50].

Our histological observations support the changes produced by 3 PFD-CD in both liver and blood serum. In hepatocytes, 3 PFD-CD induces indented nuclear membrane and perinucleolar aggregation of heterochromatin material. This suggests that a nuclear disorganization might be occurring [46], which eventually might lead to apoptosis [39]. Interestingly, the changes in mitochondria organization have been proposed to reflect a disturbance in the redox balance of the liver cell [11]. Further, damage of mitochondria is a common response of the hepatocyte to stress [29], which can undergo significant swelling to show "hydropic degeneration" [49]. It is likely that 3 PFD-CD induced vacuolation of the cytoplasm is caused by accumulation of lipid droplets, as it had been shown elsewhere [11]. Since extensive vacuole accumulation can be a cause of cell death, this further points to 3 PFD-CD as an inducer of liver damage.

In conclusion, shifting mice from protein deprivation to a complete diet three times changes both liver metabolic status and ultrastucture like it has been reported for precancerous and cancerous conditions $[33,44,48]$. These changes might have their origin in an oxidative stress caused by 3 PFD-CD. However, the mechanisms that trigger such adjustments are not entirely known and should be a focus of future work to understand the influence of nutrition on liver metabolism.

Acknowledgements This work was supported by grants to R. D.C. from the Consejo Nacional de Investigaciones Científicas y Técnicas (CONICET) and Universidad Nacional de Mar del Plata (UNMDP), Argentina. R.D.C., A.N.C., C.G.B. A.M.G. and J.R.M are career researchers of CONICET. V.J.C. and A.C. C. hold a CONICET scholarship to obtain a $\mathrm{PhD}$ degree. This work is part of the Ph.D. thesis of V. J. C.

We thank Dr. Gabriela Pagnussat for spelling and grammar corrections.

\section{References}

1. Albanes D (1987) Total calories, body weight, and tumor incidence in mice. Cancer Res 47:1987-1992

2. Ayala V, Naudi A, Sanz A, Caro P, Portero-Otin M, Barja G, Pamplona R (2007) Dietary protein restriction decreases 
oxidative protein damage peroxidizability index, and mitochondrial complex I content in rat liver. J Gerontol A Biol Sci Med Sci 62:352-360

3. Bannash P, Hacker HJ, Klimer F, Mayer D (1984) Hepatocellular glycogenosis and related pattern of enzymatic changes during hepatocarcinogenesis. Adv Enzyme Regul 22:7-121

4. Bounous G, Molson JH (2003) The antioxidant system. Anticancer Res 23:1411-1415

5. Bradford MM (1976) A rapid and sensitive method for the quantitation of microgram quantities of protein utilizing the principle of protein-dye binding. Anal Biochem 72:248254

6. Brusselmans K, Vrolix R, Verhoeven G, Swinnen J (2005) Induction of cancer cell apoptosis by flavonoids is associated with their ability to inhibit fatty acid synthase activity. J Biol Chem 280:5636-5645

7. Cho MK, Kim YG, Lee MG, Kim SG (2000) The effect of cysteine on the altered expression of class $\alpha$ and $\mu$ glutathione S-transferase genes in the rat liver during protein-calorie malnutrition. Biochim Biophys Acta 1502:235-246

8. Cho MK, Kim YG, Lee MG, Kim SG (2001) Prevention of c-Jun/activator protein-1 activation and microsomal epoxide hydrolase induction in the rat liver by cysteine during protein-calorie malnutrition. Biochem Pharmacol 61:15-24

9. Claiborne A (1985) Catalase activity. In: Greenwald RA (ed) CRC handbook of methods in oxygen radical research. CRC, Boca Raton, pp 283-284

10. Conde RD, Scornik OA (1976) Role of protein in the growth of livers after a nutritional shift. Biochem $\mathrm{J}$ 158:385-390

11. Dasgupta R, Saha I, Pal S, Bhattacharyya A, Sa G, Nag TC, Das T, Maiti BR (2006) Immunosuppression, hepatotoxicity and depression of antioxidant status by arecoline in albino mice. Toxicology 227:94-104

12. Dumas BR, Brignon G, Grosclaude F, Mercier JC (1972) Primary structure of bovine beta casein. Complete sequence. Eur J Biochem 25:505-514

13. Evert M, Schneider-Stock R, Dombrowski F (2005) Overexpression of fatty acid synthase in chemically and hormonally induced hepatocarcinogenesis of the rat. Lab Invest 85:99-108

14. Fleck A, Munro HN (1962) The precision of ultraviolet absorption measurements in the Schmidt-Thannhauser procedure for nucleic acid estimation. Biochim Biophys Acta 55:571-583

15. García-Mata R, Capdevielle J, Guillemot JC, Ferrara P, Conde RD, Sanllorenti PM (1997) Protein depletion and refeeding change the proportion of mouse liver glutathione S-transferase subunits. Biochim Biophys Acta 1357:272280

16. Grasl-Krauff B, Bursch W, Ruttkay-Nedecky B, Wagner A, Lauer B, Schulte-Hermann R (1994) Food restriction eliminates preneoplastic cells through apoptosis and antagonizes carcinogenesis in rat liver. Proc Natl Acad Sci USA 91:9995-9999

17. Habig W, Pabst MJ, Jakoby WB (1974) Glutathione Stransferase. The first enzymatic step in mercapturic acid formation. J Biol Chem 249:1730-1739
18. Hikita H, Vaughan J, Pitot HC (1997) The effect of two periods of short-term fasting during the promotion stage of hepatocarcinogenesis in rats: the role of apoptosis and cell proliferation. Carcinogenesis 18:159-166

19. Hwahng SH, Ki SH, Bae EJ, Kim HE, Kim SG (2009) Role of adenosine monophosphate-activated protein kinase-p70 ribosomal S6 kinase-1 pathway in repression of liver X receptor-alpha-dependent lipogenic gene induction and hepatic steatosis by a novel class of dithiolethiones. Hepatology 49:1913-1925

20. Ikeda H, Omoteyama K, Yoshida K, Nishi S, Sakai M (2006) CAAT enhancer-binding protein alpha suppresses the rat placental glutathione S-transferase gene in normal liver. J Biol Chem 281:6734-6741

21. James SJ, Muskhelishvili L (1994) Rates of apoptosis and proliferation vary withcaloric intake and may influence incidence of spontaneous hepatoma in C57BL/6 x C3H F1 mice. Cancer Res 54:5508-5510

22. Jones LA, Holmes JC, Seligman RB (1956) Spectrophotometric studies of some 2,4-dinitrophenylhydrazones. Anal Chem 28:191-198

23. Kuo WH, Chiang WL, Yang SF, Yeh KT, Yeh CM, Hsieh YS, Chu SC (2003) The differential expression of cytosolic carbonic anhydrase in human hepatocellular carcinoma. Life Sci 73:2211-2223

24. Laconi E, Tessitore L, Milia G, Yusuf A, Sarma DSR, Todde P, Pani P (1995) The enhancing effect of fasting/ refeeding on the growth of nodules salectable by the resistant hepatocyte model in rat liver. Carcinogenesis 16:1865-1869

25. Laemmli UK (1970) Cleavage of structural proteins during the assembly of the head of bacteriophage T4. Nature 227:680-685

26. Leduc EH (1949) Mitotic activity in the liver of the mouse during inanition followed by refeeding with different levels of protein. Am J Anat 84:397-429

27. Lii CK, Chai YC, Zhao W, Thomas JA, Hendrich S (1994) S-thiolation and irreversible oxidation of sulfhydryls on carbonic anhydrase III during oxidative stress: a method for studying protein modification in intact cells and tissues. Arch Biochem Biophys 308:231-239

28. Meyer TS, Lamberts BL (1965) Use of coomassie brilliant blue R250 for the electrophoresis of microgram quantities of parotid saliva proteins on acrylamide-gel strips. Biochim Biophys Acta 107:144-145

29. Monteith DK, Theiss JC, Haskins JR, De la Iglesia FA (1998) Functional and subcellular organelle changes in isolated rat and human hepatocytes induced by tetrahydroaminoacridine. Arch Toxicol 72:147-156

30. Oakes KD, Van der Kraak GJ (2003) Utility of TBARS assay in detecting oxidative stress in white sucker (Catostomus commersoni) populations exposed to pulp mill effluent. Aquat Toxicol 63:447-463

31. Pucciarelli MG, Conde RD (1984) Breakdown of proteins from mouse liver subcellular fractions. Effect of nutritional changes. Acta Physiol Pharmacol Latinoam 34:185-191

32. Raisanen SR, Lehenkari P, Tasanen M, Rahkita P, Harkonen PL, Vaananen HK (1999) Carbonic anhydrase III protects cells from hydrogen peroxide-induced apoptosis. FASEB J 13:513-522 
33. Ronchi VP, Conde RD, Guillemot JC, Sanllorenti PM (2004) The mouse liver content of carbonic anhydrase III and glutathhione S-transferase $\mathrm{A} 3$ and $\mathrm{P} 1$ depend on dietary supply of methionine and cysteine. Int $\mathrm{J}$ Biochem Cell Biol 36:993-2004

34. Ronchi VP, Giudici AN, Mendieta JR, Caballero VJ, Chisari AN, Sanllorenti P, Conde RD (2010) Oxidative stress in mouse liver caused by dietary amino acid deprivation: protective effect of methionine. J Physiol Biochem 66:93-103

35. Sambrook J, Fritsh EF, Maniatis T (1989) Molecular cloning: a laboratory manual, 2nd edn. Cold Spring Harbor Laboratory, New York

36. Sanllorenti PM, Tardivo DB, Conde RD (1992) Dietary level of protein regulates glyceraldehyde-3-phosphate dehydrogenase content and synthesis rate in mouse liver cytosol. Mol Cell Biochem 115:117-128

37. Sanllorenti PM, Rosenfeld J, Ronchi VP, Ferrara P, Conde RD (2001) Two dimensional non equilibrium $\mathrm{pH}$ gel electrophoresis mapping of cytosilic protein changes caused by dietary protein depletion in mouse liver. Mol Cell Biochem 220:49-56

38. Satoh K, Kitahara A, Soma Y, Inaba Y, Hatayama I, Sato K (1985) Purification, induction, and distribution placental glutathione transferase: a new marker enzyme for preneoplastic cells in the rat chemical hepatocarcinogenesis. Proc Natl Acad Sci USA 82:3964-3968

39. Shi J, Aisaki K, Ikawa Y, Wake K (1998) Evidence of hepatocyte apoptosis in rat liver after the administration of carbon tetrachloride. Am J Pathol 153:515-525

40. Tanaka K, Sano T, Ishizuka K, Kitta K, Kawamura Y (1994) Comparison of properties of leaf and root glutathione reductase from spinach. Physiol Plant 91:353-358

41. Taylor CG, Potter AJ, Rabinovitch PS (1997) Splenocyte glutathione and CD3-mediated cell proliferation are reduced in mice fed a protein-deficient diet. J Nutr 127:44-50
42. The Pharmacopeia of the USA (1955) Protein-biological adequacy test. Depletion Diet 15:882-883

43. Thomas PS (1980) Hybridation of denatured RNA and small DNA fragments transferred to nitrocellulose. Proc Natl Acad Sci USA 77:5201-5205

44. Tsuchida S, Sato K (1992) Glutathione transferase and cancer. Crit Rev Biochem Mol Biol 27:337-384

45. Wakil SJ, Stoops JK, Joshi VC (1983) Fatty acid synthesis and its regulation. Annu Rev Biochem 52:537-579

46. Wang LY, You SL, Lu SN, Ho HC, Wu MH, Sun CA, Yang HI, Chin-Jen C (2003) Risk of hepatocellular carcinoma and habits of alcohol drinking, betel quid chewing and cigarette smoking: a cohort of 2416 HbsAg-seropositive and $9421 \mathrm{HbsAg-seronegative} \mathrm{male}$ residents in Taiwan. Cancer Causes Control 14:241250

47. Wiegand C, Pflugmacher S, Oberemm A, Steinberg CEW (2000) Activity development of selected detoxication enzymes during the ontogenesis of the zebrafish (Danio rerio). Int Rev Hydrobiol 85:413-422

48. Yahagi N, Shimano H, Hasegawa K, Ohashi K, Matsuzaka T, Najima Y, Sekiya M, Tomita S, Okazaki H, Tamura Y, Iizuka Y, Ohashi K, Nagai R, Ishibashi S, Kadowaki T, Makuuchi M, Ohnishi S, Osuga J, Yamada N (2005) Co-ordinate activation of lipogenic enzymes in hepatocellular carcinoma. Eur J Cancer 41:13161322

49. Yamamoto O, Doi Y, Kudo H, Yoshizuka M, Fujimoto S (2000) Sweat gland toxicity induced by bis (tributyltin) oxide: an ultrastructural and x-ray microanalysis study. Arch Toxicol 74:627-631

50. Zimmeran HJ, Henry JB (1978) Determinaciones de las enzimas séricas como ayuda diagnóstica. In: Davidsohn I, Henry JB (eds) Todd-Sanford. Diagnóstico clínico por el laboratorio, 6th edn. Salvat, Barcelona, pp 859 889 